\title{
Resettlement Risks and Inter-Ethnic Conflict in Metekel, Ethiopia ${ }^{1}$
}

\author{
Gebre Yntiso ${ }^{2}$
}

\begin{abstract}
Involuntary displacement has the capacity to disrupt the lives of different categories of people: refugees, relocatees, and host populations. However, policymakers, donors, and researchers show inordinate concern for involuntary migrants, while the risks encountered by host people remain largely underestimated. This article compares the impacts of the 1980 s resettlement program in Metekel, Northwest Ethiopia, on the settlers and their hosts in light of conceptual constructs. It also describes how resettlement-induced conflict over resources led to bloodshed, increased displacement, reformulation of inter-ethnic alliance, and administrative complications. In addition to presenting the implications of the resettlement for the recent settlers and the original inhabitants (the Gumz people), the paper examines how other ethnic groups such as the Shinasha and the Agaw became involved in the guest-host interactions and how the ethnic-based decentralization policy was exploited to promote group interests.
\end{abstract}

\section{Introduction}

Displacement research has documented the impacts of forced migration on displaced people, namely, refugees, development-induced relocatees, and other internally displaced persons (IDPs). The literature overwhelmingly suggests that involuntary displacement involves risks of impoverishment for the displaced (Scudder 1993; Cernea 1996, 2000). What is the effect of massive influxes of people on the receiving host population? Few writers recognize that refugees and settlers strain economic resources and social services of hosts, sometimes inflicting major loss and disruption (Chambers 1986; Campbell et al 1993; Salem-Murdock 1993; Cernea 2000). Nevertheless, policymakers, donors, and mainstream displacement research continue to ignore the concern of the host people. This is evidenced by lack of adequate documentation, conceptualisation, and policy protection.

Based on research ${ }^{3}$ conducted in Metekel resettlement area, north-western Ethiopia, this paper compares and contrasts the gravity of displacement risks for

'A preliminary version of this paper was presented on the occasion of the $25^{\text {th }}$ anniversary of the College of Social Sciences, Addis Ababa University, held in Addis Ababa, Ethiopia, on 27 Dec. 2003.

${ }^{2}$ Assistant Professor, Department of Sociology and Social Anthropology, Addis Ababa University. E-mail: gebre@sosa.aau.edu.et 
the new settlers and a host population in light of Michael Cernea's impoverishment risks and reconstruction (IRR) model. It is true that the experience of forced settlers has different dynamics from that of hosts. However, the paper argues, depending on the magnitude of the impact, both groups may go through similar displacement ordeals or benefit from similar recovery measures. The lesson from Metekel reveals that massive resettlements could disrupt the livelihoods of the original inhabitants the way dams, national parks, and other development projects can displace people. In Metekel, resettlement-induced discord between the settlers and their hosts over resources led to bloody clashes, the reformulation of inter-ethnic alliance, and political/administrative complications. Therefore, while planning for resettlement all concerned parties (donors, governments, investors, etc.) should factor in the concerns of all people likely to be affected by the plan, not just the new settlers. It is important to study and determine a reasonable and acceptable settler-host ratio so that the settlers would not overwhelm the hosts and exceed the carrying capacity of resources thereby leading to impoverishment disasters and insecurity.

The research was conducted from September 1998 to December 1999. A combination of data collection techniques was employed to obtain and crosscheck information. The major tools included preliminary survey, intensive interviews, large formal surveys, panel discussions, observation, and literature review. The preliminary survey was designed to select specific research sites, identify key informants, and understand the general setting of the research area. The intensive interviews helped to elicit in-depth insight from 49 key informants $(35$ settlers and $14 \mathrm{Gumz}$ ). In order to crosscheck data from other sources and make general statements about the resettlement experience, a sample survey that involved 368 households, selected through systematic random sampling, was conducted in 16 of the 45 resettled villages. A census was conducted in one Gumz village called Manjeri to gather basic demographic and economic information. Several panel discussions were held to observe how informants discussed, argued, agreed, and/or disagreed on certain issues. Events and activities were observed as they occurred, and review of the literature continued until the manuscript was finally written.

${ }^{3}$ The Rockefeller Foundation funded the fieldwork. The Department of Sociology and Social Anthropology at Addis Ababa University, the Department of Anthropology at the University of Florida, and the Christian Michelsen Institute of Norway also assisted my study. The Center of Excellence at Kyoto University and the Japan Society for the Promotion of Science provided a fellowship that enabled me to produce this article. Acknowledgements are due to these institutions for their assistance. I am also thankful to the anonymous reviewers of the manuscript for their constructive comments. 
The paper is divided into five parts. This introduction is followed by background information on the 1980s resettlement program in Ethiopia. The third part focuses on the implications of the resettlement program for the settlers and the Gumz people. Section four discusses resettlement-induced conflicts and the reformulation of inter-ethnic relations as a coping strategy. The fifth part is the conclusion.

Figure 1. Location of Metekel
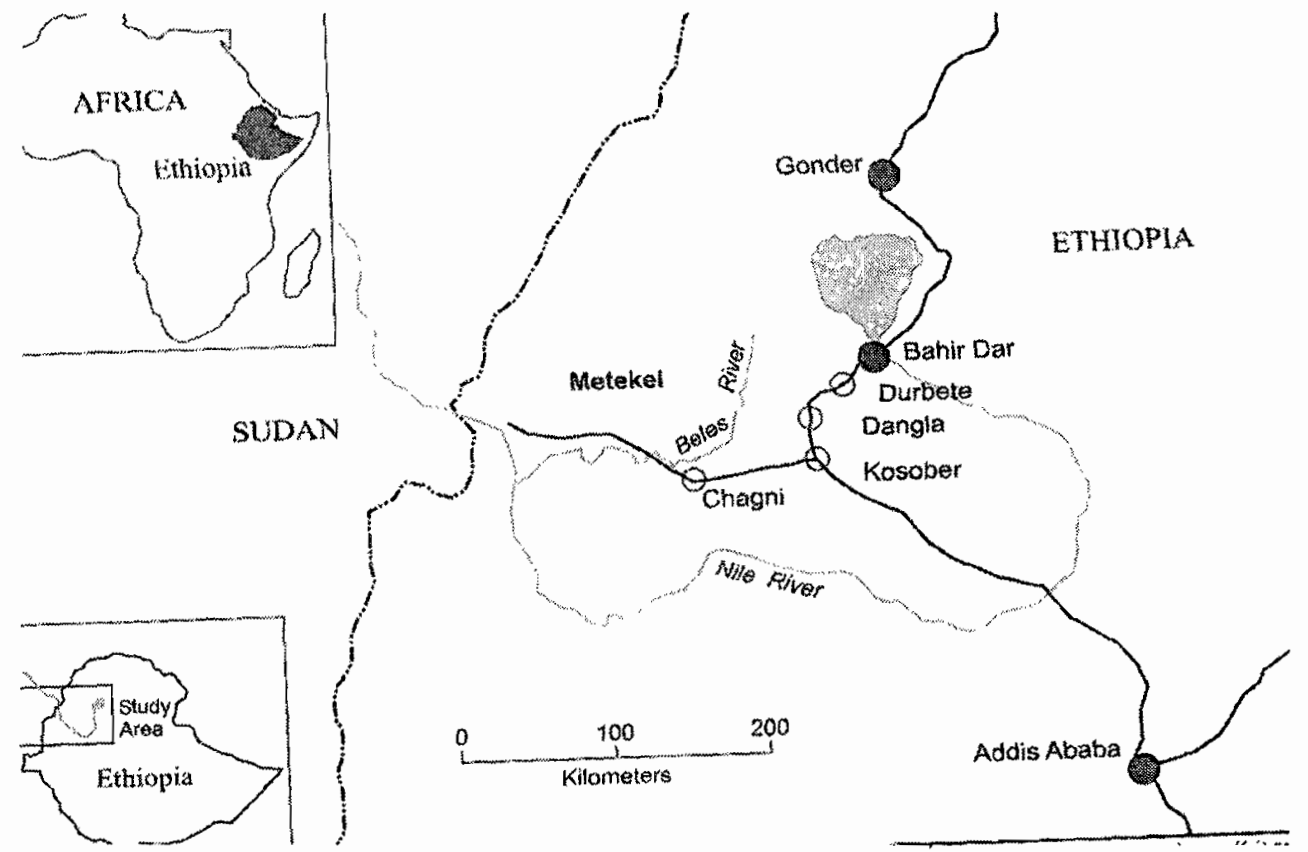

\section{Overview of the Ethiopian Resettlement}

\subsection{Rationale for Resettlement}

In October 1984, the Ethiopian government carried out an emergency resettlement program. About 600,000 people were relocated from drought-affected and overpopulated regions of the country to five major resettlement sites (namely, Metekel, Metema, Assosa, Gambella, and Kefa) located in north-western, western, and south-western parts of the country. Of this figure, over 82,000 people moved to Metekel, a place already occupied by the Gumz shifting cultivators. At the time of 
the resettlement, the population of the Gumz was estimated at 72,000 (Dessalegn 1988 in Agneta et al 1993: 256-7).

The official objective of the resettlement program was to prevent famine, reduce demographic pressure in densely populated and highly denuded highlands, and promote agricultural production in sparsely populated lowlands. The Ethiopian government portrayed the resettlement program as a durable solution to the famine problem. Given the slow reaction and/or objection of the international community (in terms of providing food aid) due to ideological reasons, ${ }^{4}$ resettlement was seen as a way out of a frustrating problem and humiliating dependency on food aid. Certain reports indicate that resettlement was recommended and supported by some western agencies. In the 1970s, the World Bank and USAID are reported to have suggested voluntary relocations from parts of Tigray and Wollo (Brüne 1990: 26), regions that were recurrently hit by drought and famine. The Ethiopian Highland Reclamation study, financed by the United Nations Food and Agricultural Organization is reported to have later supported the resettlement on environmental grounds (Dejene 1990:96).

\subsection{Criticisms and Controversy}

Western countries, particularly the USA, the UK, the Federal Republic of Germany, and most other members of the EU were opposed to the resettlement (Jansson 1990) because it was believed that people were forcibly relocated. The resettlement initiative can be regarded as forced because in October 1984 the government announced its decision to execute the emergency resettlement plan without the consent of potential settlers. There was clear determination on the part of authorities to relocate people, if necessary by force. While those people recruited in late 1984 and early 1985 welcomed the initiative and volunteered to be resettled, those enlisted after mid-1985 tried to resist the resettlement (Gebre 2001, 2002b). Critics not only questioned the sincerity of the government position, but also indicated alleged hidden motives behind the resettlement program. The government was suspected of suppressing insurgent movements by depopulating their mass base, diluting their ethnic homogeneity (Clay \& Holcomb 1986: 29; Keller 1993:233), using resettlement areas as buffer zones (de Waal 1991:221), and reorganizing the peasantry into producers' cooperatives (Dawit 1989: 289).

${ }^{4}$ After the 1974 revolutionary overthrow of the Imperial government in Ethiopia, the Derg assumed power. It soon severed relationship with the Western capitalist countries and allied with the socialist bloc until its collapse in 1991. 
Most of the settlers came from northern Ethiopia and resettled in the southwestern, western, and north-western parts of the country. Some writers explained this movement as a pattern of state-sponsored north-south migration that began a century ago (Scott 1998:248; Clay \& Holcomb 1986:28). Dejene (1990: 96-97), who belittled this argument as "an example of outsiders' superficial understanding of Ethiopian politics," asserted that the objective of the resettlement was "to restore the loss of productive land affected by drought and to use the vast amount of land in the fertile south-western region to increase food production and generate rural income." There were other counter arguments aimed at invalidating some of the criticisms. According to Kurt Jansson (1990:65), for example, the allegation that the resettlement aimed at depopulating Tigray Peoples Liberation Front's support base was unfounded as only $15 \%$ of the 600,000 settlers came from Tigray. Alula Pankhurst (1992: 79) also noted, "Recruitment from areas not under central rule was considered unwise."

Reliable documents about the decision-making processes were lacking to authenticate the various arguments and counter-arguments. I found it difficult to verify whether the resettlement was truly famine-induced, development-induced, politically-motivated, or environmentally warranted. However, there are certain indications that the famine concern being at the centre, the government may have planned for collateral advantages of resettlement. Four of the five major resettlements (Metema, Metekel, Assosa, and Gambella) were located in regions troubled by insurgent activities. Security advantages may have been factored in, as Metekel resettlement served as a source of militia force against the guerrilla fighters of the Ethiopian Peoples Revolutionary Party (EPRP). Metekel resettlement was part of a failed5 plan to connect the Beles River and Lake Tana, the source of the Blue Nile, by diverting water from the lake for power and irrigation. This suggests that the resettlement was partly development-induced. The highlanders were resettled by displacing the local Gumz people, who viewed the move as a continuation of land alienation and the expansion of state control. After their arrival in Metekel, settlers were forced to join cooperatives and work on collective farms for biweekly food ration. This is also consistent with the allegation that the resettlement was planned to promote collectivisation. When viewed in a broader context and in light of what happened, it appears that the government had multiple agendas to accomplish through resettlement.

${ }^{5}$ The Tana-Beles connection plan, which may have offended the prime users of the Blue Nile (Egypt and Sudan), was abandoned after EPRP scaled up its military offences, destroyed project machineries, and kidnapped Italians and Ethiopians working on the project (Gebre 2001). 


\subsection{Foreign Aid}

Between 1986 and 1990, Italian agencies generously funded the resettlement. The Tana-Beles Project, a giant program sponsored by the Italian Government, initiated a large-scale development scheme. Apart from relief provision, the project focused on two broad activities: production (mechanized agriculture, forestation, livestock, fishery, agro-industry, and a pipe factory) and general infrastructure (water supplies, roads, bridges, housing, stores, airport, health, education, etc.). The Italians who were running the project withdrew in the early 1990s. The International Committee for the Development of Peoples (CISP), an Italian NGO, however, sponsored small multisectoral programs from 1986 to 1999 (with brief interruption in the early 1990s due to the 1991 government change in Ethiopia). Initially, CISP promoted training and technical assistance in agriculture, forestation, handicrafts, and pre-school education. Between 1992 and 1999, CISP's limited support centred on irrigation, veterinary service, Tse-tse fly control, a revolving fund scheme, and micro-credit. Neither the giant bilateral cooperation program nor this NGO extended meaningful support to the Gumz villagers (Gebre 2003a). A Gumz informant described the exclusion of his community from the Italian projects as follows: "We were spectators when they [settlers] enjoyed the feast."

\section{Resettlement-Induced Crises}

\subsection{Implication for settlers}

The highland settlers were rushed to undeveloped and physically harsh environments (humid and malaria-ridden) without prior feasibility studies having been made and proper planning (Gebre 2003b). Since no habitable houses existed, the Metekel migrants were responsible for erecting their own huts. ${ }^{6}$ Although the government tried to provide food, the ration was so insufficient and irregular that starvation was inevitable. Moreover, the diets were nutritionally inadequate as protein and vitamin rich foods were not available. During this initial adaptation period, the incidence of morbidity and mortality was exceptionally high. According

${ }^{6}$ During the summer of 1985 , students and instructors of institutions of higher education in Ethiopia were mobilized to build thatched houses for the settlers. I participated in this national campaign as a student of Addis Ababa University. Many of the houses that we erected collapsed immediately because of weak structures. Two to five settler households (up to 20 people) were crammed into these shelters for months, until the settlers themselves built better houses. 
to informants, thousands of people perished without receiving any medical attention. Due to the excessive number of deaths per day, the dead were buried in mass graves. It was rare to find households that had never lost a member(s). The causes of sicknesses and deaths were explained through reference to malnutrition, malaria, tuberculosis, and lack of potable water. Diarrhoea was epidemic throughout the resettlement area. Alex de Waal's (1991:225-6) report confirmed the high deaths as follows.

RRC figures for recorded deaths during the first year of resettlement indicate heightened death rates: 110 per thousand in Gojjam [Meteke1], 68 in Illubabor, 42 in Keffa, 38 in Wollega and 34 in Gonder. ... The same RRC data indicate that in Pawe resettlement, Gojjam, death rates in the first four weeks of registration were equivalent to 332 per thousand per year -- almost 20 times normal.

The settlers relied on meagre government relief until the commencement of the Italian assistance in 1986. As indicated earlier, the Italians generously funded the resettlement program. The huge Italian assistance to the Tana-Beles Project made a significant impact on the food supply, health provision, basic education, housing, and water supply. However, the projects were unsustainable, as evidenced by the collapse of most of the activities following the withdrawal of the Italians in early 1990s. Salini Costruttori (1989: 14), the Italian Contractor in charge of the TBP, reported that food self-sufficiency was attained in the resettlement area in 1988. Although gross food availability increased in the resettlement area and many lives were saved, thanks to the Italians, the state of malnutrition reniained high. Some informants complained that the quantity and quality of food was inadequate. Over $31 \%$ of the sample population (of 368 settlers) were reported to have actually starved more than once during the period of Italian operation. About $49 \%$ indicated that they did not experience food insecurity, while the remaining $20 \%$ found the question not applicable for various reasons (e.g., some arrived after the Italians left). Most residents did not have access to protein and vitamin rich foods. Thus, the state of malnutrition remained significant even during the Italian assistance period. When asked to estimate the frequency with which meat appeared in their diet, many informants answered twice or three times a year. Others, particularly widows and single mothers, indicated that they had not eaten meat for years. Many sarcastically answered that they have long forgotten how meat tastes. Peas, beans, butter, and oil were so expensive that they could not afford to buy them. Vegetables were extremely scarce and inaccessible to the majority of the people. Paolo Antonioli (1992: 387) reported: 
In return for their work...the settlers were given their monthly food rations. These rations consisted basically of cereals... and small amounts of oil seeds ...plus allowances of sugar, salt, and oils. Very clearly an unbalanced diet was being provided, especially as regards protein and particularly vitamin requirements.

The migrants encountered other problems as well. They were forced to join cooperative societies for the socialist transformation of agriculture. Settlers never controlled the fruits of their labour. Instead, they worked as daily labourers for a biweekly ration, distributed according to family size rather than according to work done. This system of distribution discouraged personal responsibility and motivation to work. In 1989, a new distribution method, based on a point system, was initiated to reward devoted workers and raise productivity. A cut-off point of eight was set to measure the daily work performance of participants. Those who worked efficiently for eight hours a day were entitled to eight points. Those who lagged behind in their attendance and performance accumulated lower points, while the points given to individuals exhibiting higher efficiency than average workers exceeded the cut-off point. Due to lack of clear assessment techniques and qualified personnel to perform an objective evaluation, the overall result was disastrous, as the food income of many households declined and production never increased. In 1990, a combination of food rations, a point system, and a shareholding system was initiated to rectify the problems encountered in previous years. Households were given food ration based on their size; every individual was given Birr 1.95 (US\$0.94) for every day he/she spent on the collective farm; and participants were promised distribution of surplus according to their accumulated points. In 1991, with the change of government, the whole program stopped before the efficacy of the new system was tested.

The majority of settlers came from areas characterized by scattered settlement patterns with private farmlands located usually in outlying individual homesteads. In Metekel, however, they were forced to live in compact villages with communal farms located in outlying villages. Apart from the $1000 \mathrm{~m}^{2}$ backyard, no private land holding was allowed until the 1990s. Since no private accumulation or savings existed, most settlers remained poor and dependent on the Tana-Beles Project, which was managed by the Italians. This became evident when the foreign expatriates withdrew in 1991 - the majority had no assets to fall back on.

The Metekel resettlement had a troubled human rights record. Settlers were deprived of freedom of movement, religion, celebration of holidays, association, ceremonial/ritual performance, and social/public gathering. Movement within the resettled villages as well as outside of the resettlement area required written permission. Multiple checkpoints were established to monitor the movement of the 
settlers on a regular basis. Until 1989, according to informants, settlers were not allowed to build churches, mosques, and other places of worship. Nor were they permitted to announce their creed in public or engage in any form of religious performance or observance. In an attempt to erode their religious integrity, settlers were forced to work on Sundays and other major holidays. Funeral ceremonies, weddings, and ritual performances were also perceived as 'backward practices' that impeded development. Customary activities associated with birth, marriage, death, planting, and harvesting were all prohibited. Settlers were prevented from forming neighbourhood associations and conducting meetings. A settler described people's discontent regarding the religious restrictions as follows:

Going to the church for prayer was seen as a waste of time. Sponsoring a feast to share happiness or sorrows was seen as a waste of resources. But all people: Christians, Muslims, and Pente [Protestants], spoke alike. We told authorities that the worships and feasts are inseparable parts of our lives. But they never listened to us.

In 1991, seven years later, the Metekel settlers were not in a position to feed themselves. One informant metaphorically stated, "The nakedness [emptiness] of our lives was exposed when the Italian aid unexpectedly terminated." Ethiopian authorities took over the responsibility of running the TBP. Because of budget constraints TBP's operation was limited to supporting the project's essential staff. In 1991, the project supplied food to settlers. The following two production years (1992 and 1993) resettled households were given planted crops to weed and harvest them. Settlers were told that the project would not provide food rations any more. In 1994 and 1995, the TBP asked settlers to pay for tractor services, fertilizers, and seeds. The relationship between the project and the villagers came to an end in 1995 when the latter failed to pay the required service charges. This development resulted in a production shortfall and the 1994-96 famine in the resettlement area. Due to this economic hardship and the prevailing political and security concerns discussed later, many settlers left Metekel. The population dropped from 66,091 in 1991 to 26,660 in 1994.

In the mid-1990s, those farmers who had decided to stay in Metekel were left with one alternative: a return to plough agriculture. The challenges and opportunities encountered after this reversal are discussed elsewhere in detail (Gebre 2002a). However, it is important to highlight that the return to the plough and the reinstitution of private production was far from a smooth process. The settlers continued to face a multitude of obstacles, including shortage of oxen, deadly cattle diseases, farm labour scarcity, inability to buy fertilizers, frequent pest attacks, and striga (weed) infestation. It is equally important to note that these 
challenges were confronted with new resource-use strategies, such as the expansion and consolidation of land holding, the use of cows for traction, the hiring of labourers on family farms, and the expansion of finger millet production as a staple crop.

\subsection{Implications for hosts}

The Metekel Administrative Zone of Benishangul-Gumz Regional State is largely populated by the Gumz people, who practice shifting cultivation (also horticulture, slush-and-burn agriculture, swidden agriculture). The traditional land tenure systems of the Gumz society combined individual/household use rights with communal control. In Ethiopia, however, the practice of shifting cultivation has not been recognized as a unique socio-economic adaptation that deserves policy attention. This was evidenced by the absence of a legal provision protecting the land rights of shifting cultivators. In addition to this, places inhabited by horticulturalists have been misrepresented as unoccupied areas, wastelands, or virgin lands that can be used for settlements and/or large-scale farms (RRC 1981; Salini Costruttori 1989). It was on the basis of this presumption that the decision was made, in the $1980 \mathrm{~s}$, to resettle people largely from north Ethiopia to the Metekel lowlands.

The resettlement severely affected the lives of many Gumz communities (Gebre 2003a). For instance, the residents of Manjeri village were forced to surrender their farmlands, hunting/gathering grounds, and fishing sites to the resettlement authorities. Many families that used to live on the banks of the Beles and Little Beles Rivers were forcibly displaced and had to find other lands for their agricultural activities. Cultivated and fallow lands that belonged to the local people were allocated for settlers as residential areas and farmlands. Some informants complained that their planted crops were bulldozed to construct roads and build houses for the settlers. Many households were made land poor and landless. The villagers were physically uprooted from their homes three times. An epidemic disease that broke out in one of the resettled villages caused the first displacement in 1986. Two major bloody clashes (in 1991 and 1993) between the settlers and Gumz were responsible for two additional dislocations. The 1993 incident involved confiscation of property and burning of the entire Manjeri village into ashes.

Like most other Gumz communities, the residents of Manjeri relied on hunting for their protein supply. However, the game disappeared owing to massive deforestation. When the game disappeared, the Gumz had to switch to the meat of domestic animals. Many households could not afford to buy beef from butcher shops. Nor could they depend on domestic animals due to the prevalence of animal 
diseases and the lack of cash to buy them. In 1999, beans represented the main source of their protein food. However, it was not sufficient to compensate for the significant decline of animal protein from their diets. The Gumz used to obtain their protein supplement from fish as well. The practice of fishing declined due to security concerns in the riverbank. The residents of Manjeri refrained from going to the river for fear that the settlers might attack them. It is possible that the decline of animal protein from their diets may have caused nutritional deficiencies, the levels and consequences of which are yet to be determined through the necessary further study.

The Gumz had a long tradition of exploiting plants (shoots, flowers, fruits, leaves, and roots) from the natural environment. In bad years, gathering wild plants represented the most important survival strategy. Certain plants such as bamboo shoots and wild yams were eaten in good years as well. The clearing of forestland reduced the indigenous people's traditional access to wild edible plants. This problem was much more pronounced among the Manjeri people, who were surrounded by five resettled villages encroaching on their land. In Metekel, honey was collected largely from the ground and tree holes. The practice of honey collection had also been impaired by deforestation. In short, the loss of access to common property assets resulted in significant deterioration of food income and livelihood levels. In 1999, most members of Manjeri village were impoverished as evidenced by the lack of asset, decline of food production and access to common property resources, the consequent food insecurity and deterioration in housing, clothing, and health conditions.

\subsection{Comparison of impacts in light of the IRR Model}

The IRR model explains that forced displacement processes involve eight interlinked risks of impoverishment: landlessness, joblessness, homelessness, marginalisation, food insecurity, increased mortality and morbidity, loss of access to common property resources, and social disarticulation. Recently loss of access to education has been added as the $9^{\text {th }}$ variable (Cernea 2002). The IRR model was built to analyse the implications of development-induced resettlement for displacees, but not for host population. From the discussion above, however, it is apparent that there are parallels between the component of displacement delineated in the model and the experience of the host population in Metekel. As indicated in the summary below (Table 1), the settlers and the Gumz people experienced at least six similar risks that significantly harmed their well-being and security. Increased conflict or security concern has been added as a new risk dimension that characterizes the guest-host relationships. Based on the Metekel experience, it may 
be argued that in the context of imposed resettlement, settler-host conflict is imminent.

Table 1. Summary of impacts on settlers and hosts

\begin{tabular}{|c|c|c|}
\hline Risks & Settlers & Gumz (Hosts) \\
\hline Land & $\begin{array}{l}\text { Landless until 1994; } \\
\text { they worked on project } \\
\text { land for food ration }\end{array}$ & $\begin{array}{l}\text { Lost both cultivated and } \\
\text { fallow lands; no } \\
\text { compensation }\end{array}$ \\
\hline Home & $\begin{array}{l}\text { Initially, they lived in } \\
\text { temporary huts; } 2-5 \\
\text { households shared a } \\
\text { room }\end{array}$ & $\begin{array}{l}\text { Lost homes \& cultural } \\
\text { space of homestead } \\
\text { when they were forced to } \\
\text { evacuate villages }\end{array}$ \\
\hline Food & $\begin{array}{l}\text { Suffered from food } \\
\text { crisis in 1984-6 \& 1994- } \\
6 \text { and many perished }\end{array}$ & $\begin{array}{l}\text { Some villages (e.g. } \\
\text { Manjeri) became food } \\
\text { insecure due to loss of } \\
\text { food income }\end{array}$ \\
\hline Health & $\begin{array}{l}\text { Sickness/death } \\
\text { increased (malaria, TB); } \\
\text { death rate high in the } \\
\text { first year }\end{array}$ & $\begin{array}{l}\text { Sickness/death increased } \\
\text { (periodic) due to } \\
\text { worsening hygiene and } \\
\text { increased clashes }\end{array}$ \\
\hline CPRs & $\begin{array}{l}\text { No data on the past; and } \\
\text { now, no CPRs (e.g., } \\
\text { forest, grazing field) }\end{array}$ & $\begin{array}{l}\text { Access to forest and rivers } \\
\text { lost/declined due to } \\
\text { deforestation and security }\end{array}$ \\
\hline Power & $\begin{array}{l}\text { No freedom movement, } \\
\text { worship, etc.; were } \\
\text { dependent on project }\end{array}$ & $\begin{array}{l}\text { Until 1991, they have been } \\
\text { marginalized; neglected; } \\
\text { and their rights violated }\end{array}$ \\
\hline Security & $\begin{array}{l}\text { Many killed; wounded; } \\
\text { felt at risk due to deadly } \\
\text { conflict with the host }\end{array}$ & $\begin{array}{l}\text { Many killed; wounded; } \\
\text { felt at risk due to deadly } \\
\text { conflict with the settlers }\end{array}$ \\
\hline
\end{tabular}

NB. CPR stands for common property resource (see Kibreab 2000 for definition).

\section{Conflict and Inter-Ethnic Relations}

\subsection{Historical relations}

In order to understand the escalation of conflict and recent changes in inter-ethnic alliance in Metekel, it is important to examine the historical relations of the various groups in the area. The old neighbours of the Gumz ethnic group include the Kulsi, the Agaw, the Shinasha, the Oromo (of Wollega region), and the Amhara (of Gojam and Gonder regions). Historically, the Gumz (and the little studied Kulsi), who exhibit distinct cultures and physical appearance from the rest of the ethnic 
groups in the area, were subjected to discrimination and subjugation by their powerful neighbours.

Elderly Gumz informants indicated that their ancestors originally occupied a territory to the east of Metekel up to Lake Tana, the source of the Blue Nile. Over a long period of time, they were pushed towards Metekel lowland by the Amhara and Agaw people, supported and encouraged by the state. According to them, slavery, appropriation of property, and violence characterized their relationship with the aggressors. Documentary evidence support these allegations (Cerulli 1956; James 1986:119-120; Taddesse 1988:11-13; Morell 2000:23-23). During the reign of Sertse-Dengel (1563-97), the Abyssinian state (old kingdom in present-day northern Ethiopia) made many aggressive attempts to incorporate the Gumz and bring their natural resources under its direct control (Taddesse 1988). Cerulli (1956:15) wrote that in 1587 Sertse-Dengel went to Belaya and subdued a Gumz tribe called Wambarya. These offensives were reported to have continued during the reigns of Susneyos (1607-32), Fasiledes (1632-67), and Yohannes (1667-83), and it was during the reign of Iyasu the Great (1683-1706) that the state made the final breakthrough among the Gumz (Taddesse 1988).

Later, the region was attached to Ethiopia, the writer noted, through a system of indirect rule where the local leaders of the neighbouring groups were assigned as administrators (Taddesse 1988). James Bruce (1790) reported that in the 1770s the Gumz were controlled by Abyssinia. The writer indicated that the residents of Metekel paid tribute in gold, and such payments were effected through the Agaw intermediaries (Ibid: 737-739). The indirect rule continued until Hailu Teklehaimanot of Gojam came to power and appointed his own [Amhara] people to control the resources of Metekel (Abdussamad 1988:238). Until early 1990s, appointed non-Gumz officials governed the Metekel province and its districts. The Amhara rulers had dominated the Agaw, Oromo, and Shinasha as well. However, the Gumz viewed officials from these ethnic groups as agents of the state and the Amhara. Conflict and distrust characterized the historical relationships between the Gumz and these groups.

\subsection{Resistance and Conflicts}

The pressure on the Gumz people and their land continued even after they were being pushed to the lowlands. The people had not been passive recipients of the external threats. Members of the Gumz society expressed their objection to encroachment through a variety of ways, including violent confrontation. In the 1960 s, for example, the Gumz people resisted the self-initiated resettlement of highlanders in Metekel. They tried to expel new settlers from Mentawuha, Deq, 
and other areas. In response to this, the government sent an army, led by the late Major Lemesa Bedaso and Qegnazmach (an old feudal title) Adamu Bekele to silence Gumz opposition. According to informants, the forces of Major Lemesa and Qegnazmach Adamu destroyed the resistance movement in Dibate and Mandura districts, respectively. The Gumz were disarmed and forced to accommodate the settlers, while the latter were allowed to keep their weapons for self-defence.

The 1980s resettlement program also triggered Gumz resistance and deadly conflict. Initially, alleged Gumz assassins killed settlers on the road, in the forest, in the fields, and even in their homes. The government dispatched militiamen (recruited from among settlers) and police forces to protect the settlers. Continued killings and retaliatory actions triggered direct confrontations between the Gumz, on the one hand, and the settlers and their defenders, on the other. In 1985/6, the first reportedly heavy fighting broke out in Gulbak (also Gublak), one of the early resettlement sites. During this clash, an unknown number of people are said to have died and wounded from both sides. In 1987, partly for security reasons, the entire eight villages (9520 settlers) in Gulbak were transferred to the main resettlement in Pawe area,

On 25 January 1987, settlers in the Pawe scheme ${ }^{7}$ clashed with the Gumz near a resettled village called L28 (Tana Beles Project 1990). The origin of this incident was explained in relation to conflict over land between the Gumz and two resettled villages, L28 and L29. This clash was reported to have temporarily suspended transportation and project activities in the vicinity of the contested area. After this incident, according to informants, tension escalated and individuals continued to be victimized here, there, and everywhere. Many resettled villagers sharing common boundaries with the Gumz communities reported to have lost members at the hands of their hostile neighbours. Banchamlak Chane of village L131 was gunned down on the road while returning home from a mill shop in Almu town. Tsegaye Negash (herder) and Ahmed Husen (farmer), both from L131, were killed in the woods. In village L2, Habtu Melak was slain in his house during the night; Dagnaw Gebre was killed in his farmland; and Beqachew Mengistie was found shot by the riverside. Ayehew Kebkab of village RUS 46 and two women from RDS 49 were shot dead in the forest.

${ }^{7}$ The Metekel resettlement scheme was established on both sides of the Beles River. Each village is identified by a number with $L, R, R H, R D S$, or RUS as its prefix. All villages on the left hand side of the river course carry $L$, while those on the right hand side are differentiated by $R$. Few villages on the $\mathrm{R}$ side are given the labels RH (Right Hand), RUS (Right Upside) and RDS (Right Downside) to denote their direction from the main road heading to Guba town, located near the Ethio-Sudan border. 
The Gumz informants, on their part, accused the settlers of killing innocent people. Yigzaw Andarge, a resident of Manjeri village, was brutally beaten to death in village LA. Yigzaw shot dead one of his attackers (a settler) before he was overpowered and killed. A woman from Manjeri was also killed near Almu town while she was heading to the town to sell firewood. Her friend, who narrowly escaped the assault, witnessed that the killers were settlers. A woman from Gitsa village was slain near village $L 2$. An unknown assassin gunned down Dinewa Gas at his home in Aypapa village, a place close to resettled villages called RH 101 and RH 127. Some unknown number of Gumz men travelling by car were stopped and killed at RDS 49. The random slayings culminated in the following series of bloody clashes that left hundreds dead in the early 1990s.

An incident broke out in 1991 on a day many Gumz people gathered for Dinewa Gas' "kemisha" (memorial service) in Aypapa village. It is said that the family of Dinewa believed that settlers from the neighbouring villages got away with the murder. During the memorial service, some participants (relatives) requested the family of the deceased man to slaughter animals for the service. The female relatives of Dinewa, who had been expecting vindictive acts, challenged the rightness of the request for meat when the death of their loved one remained unaccounted for. The challenge sensitised young men, who sneaked out of the event to take revenge on settlers without alerting their fellow people. They killed two settlers from the nearby villages. The settlers retaliated by killing four Gumz who were returning from the memorial service ( 2 women from Azarti, a man from Manjeri, and a woman from Deq areas).

In the same year, another incident occurred during Make Ambra's (Gumz) burial ceremony in Manjeri village. Gumz mourners from different villages attended the funeral. A drunken settler from the neighbouring resettled village (L4) unintentionally shot Mekuria Jemos (Gumz) while trying to pass his condolence by firing bullets into the air. The death of Mekuria turned the calm mourners into angry mob. After killing the gunman, the mob attacked village $L A$ and massacred about 57 settlers, most of whom were ethnic Kembata and Hadiya. Moreover, the attackers looted the property of the victims. In terms of legal action, nothing much was done other than indemnifying the victim's relatives (which the Gumz paid in cash) and retrieving some of the goods looted during the raid.

A clash broke out when Gumz men from Gitsa village attempted to attack village $\mathrm{L} 2$ to retaliate for the death of their woman who was supposedly killed by a settler. The Gumz occupied one side of the Piza River (also Gilgel Beles) and the settlers fortified on the other side. They exchanged gunfire until government soldiers arrived from the settlers' side and pushed the Gumz force back. During the shootout, informants witnessed two government soldiers being killed and another 
two seriously wounded. No other casualty was reported. Later on, the Gumz gave an ultimatum to the residents of L2 that they must either pay an indemnity or wait for a revenge. The tension eased after $\mathrm{L} 2$ villagers paid animals and cash as an indemnity for the death of the Gumz woman.

In village L131, fighting took place in July 1993 following the murder of a settler called Ahmed Husen in his field. In retaliation for his death, Ahmed's friends ambushed and fired at Gumz people, who happened to carry guns and fired back. A settler (from Gojam) was seriously wounded during this exchange of gunfire. Police arrived on the scene and cooled down the tension by promising the settlers that the criminal(s) would be caught. On the night of this incident, the wounded settler's friends and relatives from villages L9, L10, and L24 gathered at village L131 to launch a surprise attack on the nearby Gumz village. Hundreds of combatants marched towards their target early in the morning. The Gumz force that controlled strategic positions in anticipation of a possible enemy advance launched a surprise attack and humiliated the settlers. While village L131 lost four people, the casualties sustained by the other three villages and the Gumz remained unknown.

Another violent incident occurred when residents of village L134 attacked a Gumz village called Wendibil to get back grain allegedly taken by the Gumz. The Gumz, who dismissed the accusation, complained that the settlers confiscated their property during the raid. According to the residents of Wendibil, the objective of the settlers' attack was to intimidate the Gumz and retain the farmlands the settlers had acquired illegally. No human casualties were reported. However, the incident created mounting tension until government officials and local mediators intervened to resolve the land dispute. According to the resolution, settlers could not use new lands other than the ones bulldozed during the Italian assistance. Those who acquired new land without permission were ordered to surrender the land to the Gumz. It was also agreed that the Gumz could not claim access to or control over land cleared by the Tana-Beles Project.

The most devastating incident started in September 1993 when unidentified gunmen opened fire in a market place, in broad daylight, and killed 21 people. To date, the identities of the gunmen and their motives remain mysterious. Nevertheless, the settlers and the Gumz have been accusing each other for the massacre. Besides denying any connection to this atrocity, each group has made presumptions that would implicate the other group. The settlers believed that Gumz officials and their associates (from Shinasha and Agaw ethnic groups) agitated the ordinary Gumz to rise against the resettled population. They argued that the motivation behind the mass murder of market-goers included controlling political power, driving settlers out of Metekel, and controlling the TBP resources. On the 
other hand, the Gumz maintained that the leaders of the settlers planned and executed this crime. They believed that the conspirators plotted the crime with the objective to implicate Gumz leaders, impair the decentralization process that empowered the Gumz, retain Amhara domination, and control TBP resources.

In an alleged retaliation for the market day massacre, organized settlers kidnapped Gumz and Shinasha officials for execution. Some officials tried to save their lives by taking refugee with the Gumz militiamen stationed in the zonal capital - Almu. However, the army of the new government required the militias to surrender their weapons. When the militias refused to comply, electric power and water supplies were cut off for about 24 hours in an attempt to force them to surrender. Full scale fighting erupted between the army and the Gumz militiamen. Of an estimated 75 militiamen, about 50 were believed to have died during this combat. When the militias were subdued, the Gumz officials under their protection were caught by the settlers for another round of execution. Two Gumz officials (Engineer Geremew Flate and Engineer Tigre) and two Shinasha officials (Damtew Gobena and Asefa Aynama) were among victims slain in front of the crowd. The crowd then marched on Manjeri village, crushed the defensive resistance, burned the entire village, and confiscated the property of the residents. Since then, the tension between the settlers and the Gumz has been reduced, if not avoided, by disarming both groups and through reconciliation arbitrated by government officials. ${ }^{8}$

\subsection{Changing Inter-ethnic Alliance}

Prior to the 1980 s, the Gumz were defensive in terms of protecting their territory against Agaw encroachment. They also maintained cautious and measured relations with the Shinasha. The 1980s resettlement, the conflict between the new settlers and the Gumz, and the 1991 government change in Ethiopia altered inter-ethnic alliance and compassion in Metekel. In the 1980s and 1990s, the Gumz, the Shinasha, and the Agaw became close allies to the extent of alarming many settlers, who then wondered that the associates of the Gumz might have plotted the violent attacks perpetrated against them. The new inter-ethnic alliance created favourable conditions for the old neighbours, particularly the Agaw farmers, to resettle in the vicinity of Gumz villages. In Manjeri, for example, eight Agaw households (48 people) had arrived beginning in 1994, and eight more households were expected to come in 2000. Similar resettlements were taking place in other Gumz villages as well.

\footnotetext{
${ }^{8}$ Data are not available on the actual process of the reconciliation that took place in $1994 / 5$.
} 
The recent ethnic-based regionalisation process seemed to facilitate the alliance between the Gumz and their immediate neighbours. Initially, concepts like balebet (owners or natives), newari (residents), and sefari or metie (settlers or migrants) have been used in the political discourse to define people's rights to natural resources and self-government. The regionalisation process appeared to empower the natives (Gumz) and the permanent residents (Shinasha). For example, members of these groups held key political and administrative positions in the Metekel Zone that consisted of seven districts. The settlers constituted one district and were represented in the zonal council. In terms of sheer size and political power, the representatives of the natives and the residents, who came from the other six districts, overwhelmed the migrants.

The competing groups in Metekel tried to exploit the decentralization policy to protect their rights and promote group interest. The natives and the long-stayed residents embraced the ethnic-based regionalisation principle to ensure economic and political control over Metekel. The Gumz in particular considered the new political development as an opportunity to put an end to the Amhara domination and reverse the course of history. Some even hoped to regain the land they lost to the settlers in the 1980s. The Agaw and the Shinasha, who also had bitter resentment against the previous Ethiopian regimes for being marginalized, welcomed the new self-government ideals. The administrative restructuring of Metekel ${ }^{9}$ provided the natives and the residents an officially sanctioned ground to collaborate.

The settlers, who felt that they were treated as second-class citizens with restricted rights to live and work in Metekel, demanded that the notion of selfadministration should apply to them as well. Some of their leaders are reported to have advocated administrative attachment of the resettlement area to the neighbouring Amhara Region, the region from which most of the settlers originated. This agitated the Gumz activists to demand the evacuation of the settlers from Metekel. The extreme positions held by both sides led to tension and the bloodshed described earlier. The compromise reached, through government intervention in 1994, was to recognize the resettlement area as a special district answerable to the regional government bypassing the Gumz-dominated Metekel Zone. During the research period, administratively, the district was under Benishangul-Gumz Region. However, the political party that controlled power in

${ }^{9}$ Prior to 1991 , Metekel was a province of Gojam Region. Most of the residents of Gojam belong to the Amhara ethnic group. The Gumz, Agaw, Shinasha, and Kulsi are minorities. According to the new administrative structure, Metekel is a zone under Benishangul-Gumz Region (see figure 1). This region is inhabited by several ethnic groups. 
the district was the Amhara National Democratic Movement - ethnic-based party operating primarily in the neighbouring Amhara Region. In other words, the resettlement area is linked administratively to one region and politically to another. Under conditions of unanimity, some district officials admitted that this dual affiliation has complicated and hampered the business of running the district.

What does it mean for the ordinary Gumz people to welcome the Agaw and resist the resettlement of the Amhara? The legal land rights of the Gumz shifting cultivators were unclear. In the past, authorities considered fallow fields and forest areas as unoccupied lands, and designated them as state farms, resettlement areas, and commercial farms. Strategically, therefore, the Gumz were trying to maintain control over the remaining lands by passing holdings on to people whom they knew and trusted. The Agaw obtained land through sharecropping arrangement or renewable contracts. Out of a total of 97 Gumz households in Manjeri village, 47 percent reported that they had rented their land. ${ }^{10}$ Many informants indicated that this practice would serve as safeguards against arbitrary dispossession by the government or by the Amhara. At the same time, they did not preclude the possibility that their Agaw guests may become permanent residents and claim control over land. Politically, therefore, welcoming the Agaw represented an expression of resistance against the Amhara expansion into their territories. The economic advantage was that the Gumz could generate income to cope with the overall resettlement-induced livelihood deterioration. Moreover, some Gumz appeared to be motivated to learn the plough system from the Agaw.

\section{Conclusion}

The analysis of the 1980s resettlement program in Ethiopia in light of the IRR model reveals that resettlement has the potential to affect both the settlers and host people in multiple ways that are comparable. Moreover, my research shows that inadequately planned and poorly managed resettlements are likely to involve competition and deadly conflicts over resources that might be scarce or abundant. The ideal solution to avert displacement-induced impoverishment disasters and social disorder would be to avoid involuntary relocation and to recognize the inalienable rights of local people to their natural resources. When resettlements are unavoidable for justified reasons, careful measures should be taken to mitigate

${ }^{10}$ Some Gumz leased their land to the settlers, as there were not many Agaw families. It is important to note that different codes of agreement were followed. While the Agaw were allowed to establish homes and live in Gumz villages, the settlers were not given residential permits. The contracts with the settlers were renewed annually, while the Agaw enjoyed longer or unspecified lease periods. 
adversities. Government planning for resettlement should have clear policy and legal frameworks. A reasonable and acceptable settler-host population ratio should be determined so that the settlers do not overwhelm the hosts and exceed the capacity of the area for sustaining the population. Resettlement plans should be based on comprehensive feasibility studies undertaken by qualified researchers with interdisciplinary backgrounds. The potential settlers and host populations should be consulted in advance to secure their full consent and active participation in the decision-making processes. The construction of homes, the development of infrastructure and social services, and the commencement of production activities should start before the actual relocation to make the transition smooth and less disruptive. Resettlements must be planned on the basis of development approaches that transcend mere replacement or restoration of the existing standards of living. Donor agencies sponsoring resettlements should study the host areas and ensure that the concerns of relocated populations and the original residents are adequately addressed. 


\section{REFERENCES}

Abdusamad Ahmed. 1988, "Hunting in Gojam: The Case of Metekel 1901-1932." In Taddese Beyene, ed. Proceedings of Eighth International Conference of Ethiopian Studies, ed.vol.1, pp. 237-244. Addis Ababa.

Agneta, F., S. Berterame, M. Capirci, L. Magni, and M. Tomassoli. 1993. "The Dynamics of Social and Economic Adaptation During Resettlement: The Case of Beles Valley in Ethiopia" In Michael M. Cernea \& S. E. Gugggenheim, eds. Anthropological Approaches to Resettlement: Policy, Practice, and Theory. Boulder: Westview Press, 251-282.

Antonioli, P. 1992. "The Cornerstones of Development: Training, Private Cooperatives, Marketing Strategies, and Handing Over." In Paolo Dieci \& C. Viezzoli, eds. Resettlement and Rural Development in Ethiopia, Social and Economic Research, Training and Technical Assistance in the Beles Valley. Milano: Franco Angeli., 383-396.

Bruce, J. 1790. Travels to Discover the Sources of the Nile. Edinburgh: J. Ruthven. Brüne, S. 1990. "The Agricultural Sector." In Siegfried Pausewang, F. Cheru, S. Brüne, \& E. Chole, eds. Ethiopia: Rural Development Options. London: Zed Books, 17-28.

Campbell, P. J., Debra Kreisberg-voss, and Joy Sobrepena. 1993. The UNHCR and the International Refugee Protection System: Resources and Responses in Refugee Empowerment and Organizational Change: A Systems Perspective, Peter W. van Arsdale, ed. pp. 155-180. Arlington, VA: American Anthropological Association.

Cernera, M. 1996. "Understanding and Preventing Impoverishment from Displacement-Reflections on the State of Knowledge" In C. McDowell, ed. Understanding Impoverishment: The Consequences of. Development-Induced Displacement. Oxford: Berghahn Books, 13-32. 2000. "Risks, Safeguards, and Reconstruction: A Model for Population Displacement and Resettlement" In Michael Cernea \& Christopher McDowell, eds. Risk and Reconstruction Experiences of Settlers and Refugees. Washington, DC: The World Bank, 11-55.

.2002. "Advances in resettlement theory and policy and the economic basis of successful resettlements." Paper presented for the International Symposium on Resettlement and Social Development, held at Hohai University, Nanjing, China.

Cerulli, E. 1956. Peoples of Southwest Ethiopia and Its Borderland. London: International African Institute. 
Chambers, R. 1986."Hidden Looser? The Impact of Rural Refugees and Refugee Programs on Poorer Hosts" In D. Gallapher, ed. Refugees: Issues and Directions, A Special Issue, International Migration Review, vol. 20, pp. 245263. New York: Center for Migration Studies.

Clay, J. W. \& B. K. Holcomb. 1986. Politics and the Ethiopian Famine 1984-1985.

Cambridge: Cultural Survival.

Dawit Wolde Giorgis. 1989. Red Tears: War, Famine and Revolution in Ethiopia.

Trenton. N.J.: The Red Sea Press

De Waal, A. 1991. Evil Days: Thirty Years of War and Famine in Ethiopia. New York: Human Rights Watch.

Dejene Alemneh. 1990. Environment, Famine, and Development in Ethiopia. Boulder: Lynne Rienner.

Dessalegn Rahmato. 1988. "Some Notes on Settlement and Resettlement in Metekel Awraja (Gojjam Province)." In Gromyko, A, ed. Proceedings of the Ninth International Congress of Ethiopian Studies. USSR Academy of Sciences, Africa Institute. Moscow: Nauka Publishers, 26-29.

Gebre Yntiso. 2001. Population Displacement and Food Insecurity in Ethiopia: Resettlement, Settlers, and Hosts. (Ph.D. Dissertation, Depart. of Anthropology, University of Florida.)

2002a. "Differential Reestablishment of Voluntary and Involuntary Migrants: The Case of Metekel Settlers in Ethiopia." African Studies Monographs, 23(1): 31-46.

2002b. "Contextual Determination of Migration Behaviors: The Ethiopian Resettlement in the Light of Conceptual Constructs." Journal of Refugee Studies, 15(3):265-282.

2003a. "Resettlement and the Unnoticed Losers: Impoverishment Disasters among the Gumz Hosts in Ethiopia." Human Organization, vol. 62, no. 1 (In press)

2003b. "The Metekel Resettlement in Ethiopia: Why Did It Fail?" Paper presented for a Joint Workshop Organized by the United Nations Emergencies Unit for Ethiopia and the Ethiopian Society of Sociologists, Social workers, and Anthropologists on "Settlement and Resettlement in Ethiopia: Population Displacement, Pastoralist Sedentarization, and Peace-Making," held on 28-30 January 2003, Addis Ababa, Ethiopia

James, W. 1986. "Lifelines: Exchange Marriage Among the Gumz" In Donald Donham and Wendy James, eds. Southern Marches of Imperial Ethiopia: Essays in History and Social Anthropology. Cambridge: Cambridge University Press, 119-147. 
Jansson, K. 1990. The Ethiopian Famine. Revised and updated edition. London: Zed Books.

Keller, E.J. 1993. "Government Politics.” In Thomas P. Ofcansky \& LaVerle Berry, eds. Ethiopia: A Country Study/ Federal Research Division, Library of Congress. Washington, DC: US Government Printing Office, 209-266.

Kibreab Gaim. 2000. "Common Property Resources and Resettlement." In Michael M. Cernea and Christopher McDowell, eds. Risk and Reconstruction Experiences of Settlers and Refugees. Washington, DC: The World Bank, 293-331.

Morell, V. 2000. “The Blue Nile: Ethiopia's Sacred Waters." National Geographic. $198(6): 2-29$.

Pankhurst, A. 1992. Resettlement and Famine in Ethiopia: The Villager's Experience. Manchester: Manchester University Press.

RRC (Relief and Rehabilitation Commission of Ethiopia). 1981. Settlement Policy. Addis Ababa: RRC

Salem-Murdock, M. 1993. "Involuntary Resettlement: A Plea for the Host Population." In Anthropological Approaches to Resettlement: Policy, Practice, and Theory, eds., , pp. 307-320. Boulder: Westview Press. Michael M. Cernea \& Scott E. Guggenheim

Salini Costruttori. 1989. The Tana-Beles Project Ethiopia. Rome: Salini Costruttori. Salem-Murdock, M. 1993. "Involuntary Resettlement: A Plea for the Host Population" In Michael M. Cernea \& Scott E. Gugggenheim, eds. Anthropological Approaches to Resettlement: Policy, Practice, and Theory,. Boulder: Westview Press, 307-320.

Scudder, T. 1993. "Development Induced Relocation and Refugee Studies: 37 Years of Change and Community Among Zambia's Gwambe Tonga." Journal of Refugee Studies, vol. 6, no. 2, 123-152.

Taddesse Tamrat. 1988. "Nilo-Sahara Interactions with Neighboring Highlanders: The Case of the Gumz of Gojjam and Wallaga." In Proceedings of the Workshop on Famine Experience and Resettlement in Ethiopia. IDR, Addis Ababa University, 7-15. 
